\title{
International Remittances, Domestic Remittances, and Income Inequality in the Dominican Republic
}

\author{
Ayal Kimhi ${ }^{1, *}$ \\ ${ }^{1}$ Department of Environmental Economics and Management, The Robert H. Smith Faculty of \\ Agriculture, Food and Environment, The Hebrew University of Jerusalem, Israel \\ *Corresponding author: Department of Environmental Economics and Management, The \\ Robert H. Smith Faculty of Agriculture, Food and Environment, The Hebrew University of \\ Jerusalem, Israel. E-mail: ayal.kimhi@mail.huji.ac.il
}

Received: January 13, 2020

Accepted: August 18, 2020 Published: September 18, 2020

doi: 10.5296/rae.v12i3.16235

URL: https://doi.org/10.5296/rae.v12i3.16235

\begin{abstract}
Inequality decomposition techniques are used to analyze the different impacts of domestic and international remittances on household income inequality in the Dominican Republic. This analysis highlights the importance of the distinction between domestic and international remittances as drivers of inequality as well as the importance of identifying and quantifying the determinants of remittances and their subsequent impact on inequality. Domestic remittances are found to be more equalizing than international remittances. Education leads to lower domestic remittances and higher international remittances, reflecting the role of education in promoting international versus domestic migration. Schooling increases inequality through domestic remittances and decreases inequality through international remittances.
\end{abstract}

Keywords: Latin America and the Caribbean, Dominican Republic, remittances, inequality, decomposition, education 


\section{Mll Macrothink}

\section{Introduction}

Despite evidence for negative impact of out-migration on the economy due to brain drain (Adams, 2003), remittances from migrants have contributed significantly to income in sending communities. Adams and Page (2005), Pfau and Giang (2009), Jimenez-Soto and Brown (2012), Imai et al. (2014), Bang, Mitra, and Wunnava (2016), Vacaflores (2018), Kóczán and Loyola (2018) and Azizi (forthcoming) have shown that an increase in international remittances reduces poverty in developing countries. However, other studies have found both positive and negative effects of remittances on poverty and inequality in various countries (Taylor, 1999; Acosta et al., 2008; Möllers and Meyer, 2014; Brown and Jimenez-Soto, 2015). Theoretically, remittances are likely to increase inequality at initial stages of the migration process and reduce inequality at later stages (Özden and Schiff, 2006; Rapoport and Docquier, 2006). This prediction is supported by the empirical findings of Stark, Taylor and Yitzhaki $(1986,1988)$ and Taylor et al. (2008). The latter also differentiated between domestic and international remittances, and showed that they had different effects on inequality and poverty in rural Mexico. Adams (2011) reviewed the empirical literature and reported that international remittances generally have positive impacts on poverty but could have negative impact on labor supply, education and growth.

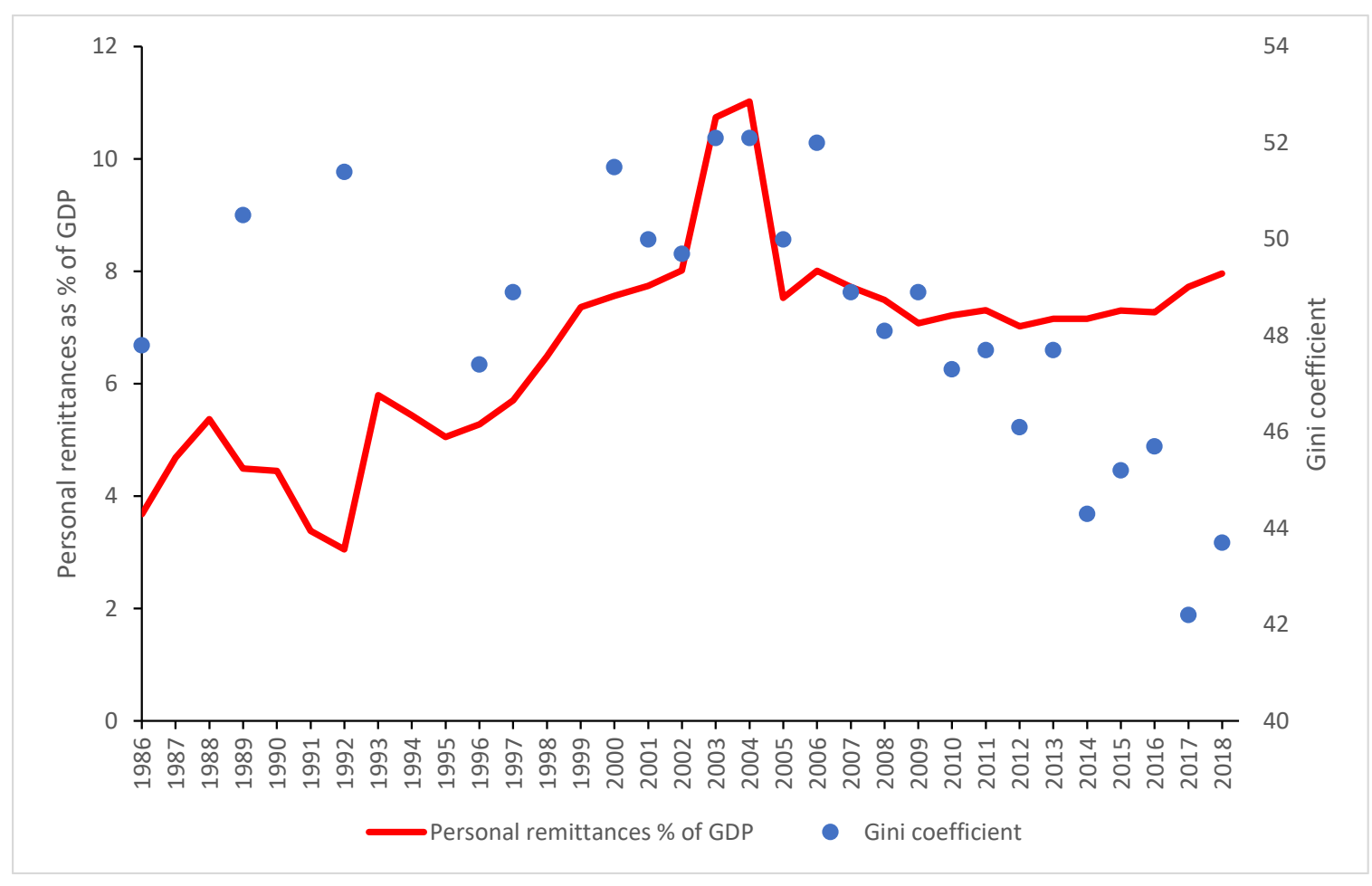

Source: The World Bank

Figure 1. Remittances and Inequality in the Dominican Republic

The purpose of this paper is to investigate the impact of domestic versus international remittances on household income inequality in the Dominican Republic. Despite impressive 
growth performance since about 1970, poverty and inequality remain important issues in the Dominican Republic (Carneiro et al., 2016). The country has a rich history of rural-to-urban migration as well as international out-migration, especially to the U.S. (Pessar, 1982). Personal remittances have increased dramatically since the mid-1980s up to the early 2000s (figure 1), and are conceived as a potentially equalizing income source (Vacaflores, 2018). However, the Gini index of inequality hardly changed up to the early 2000s (figure 1). These trends have changed since the recession of the early 2000s. During a relatively rapid growth period, the fraction of remittances stagnated, while inequality started decreasing. Hence, the link from remittances to inequality is complex and requires a more refined analysis.

Fajnzylber and Lopez (2008) found that the observed Gini index in the Dominican Republic is slightly higher that what it would have been without migration and remittances. They used a comparison of the actual and counterfactual income distributions, with the latter based on simulating household incomes in the absence of migration and remittances, and did not distinguish between domestic and international remittances. While total remittances as a fraction of household income was roughly constant across income quintiles in the Dominican Republic in 1998, the share of international remittances in total remittances was $60 \%$ in the highest quintile but only $20 \%$ in the lowest quintile (World Bank, 2000). Therefore, the distinction between domestic and international remittances is very important for the analysis of inequality in the Dominican Republic.

This paper uses inequality decomposition techniques in order to obtain marginal effects of domestic and international remittances on inequality, a method that has been applied to other countries before (e.g., Stark, Taylor and Yitzhaki, 1986). Two decomposition rules are used. Shorrocks (1982) and Fields (2003) suggested that the squared coefficient of variation has superior theoretical properties. On the other hand, the decomposition of the Gini index of inequality is more intuitively appealing and offers an analytic formula for the marginal effects (Lerman and Yitzhaki, 1985). Previous research has shown that the results of the two decomposition rules are mostly but not always consistent (Shorrocks, 1983; Morduch and Sicular, 2002; Kimhi, 2007). This paper compares the results of the two rules, by obtaining marginal effects for the squared $\mathrm{CV}$ rule using a simulation exercise.

The next section describes the methodology of inequality decomposition by income sources. The following section presents the decomposition results and the marginal effects. After that we analyze the determinants of remittances and their inequality implications. Subsequently, we decompose the contributions of remittances to inequality further, by the determinants of remittances. The final section summarizes the results.

\section{Methodology}

Shorrocks $(1982,1983)$ suggested focusing on inequality measures that can be written as a weighted sum of incomes:

(1) $I(\mathbf{y})=\Sigma_{i} a_{i}(\mathbf{y}) y_{i}$, 
where $a_{i}$ are the weights, $y_{i}$ is the income of household $i$, and $\mathbf{y}$ is the vector of household incomes. If income is observed as the sum of incomes from $k$ different sources, $y_{i}=\Sigma_{k} y_{i}{ }^{k}$, the inequality measure (1) can be written as the sum of source-specific components $S^{k}$ :

(2) $I(\mathbf{y})=\Sigma_{i} a_{i}(\mathbf{y}) \Sigma_{k} y_{i}^{k}=\Sigma_{k}\left[\sum_{i} a_{i}(\mathbf{y}) y_{i}^{k}\right] \equiv \Sigma_{k} S^{k}$.

Dividing (2) through by $I(\mathbf{y})$, one obtains the proportional contribution of income source $k$ to overall inequality as:

(3) $s^{k}=\Sigma_{i} a_{i}(\mathbf{y}) y_{i}^{k} / I(\mathbf{y})$.

Shorrocks (1982) noted that the decomposition procedure (3) yields an infinite number of potential decomposition rules for each inequality index, because in principle, the weights $a_{i}(\mathbf{y})$ can be chosen in numerous ways, so that the proportional contribution assigned to any income source can be made to take any value between minus and plus infinity. He further showed how additional intuitive restrictions on the choice of weights can reduce the number of potential decomposition rules, and came up with a unique decomposition rule based on the squared coefficient of variation inequality index. Fields (2003) reached the same conclusion in a different way. However, Shorrocks (1983) still suggested not to rely solely on this decomposition rule in empirical analyses.

The decomposition results indicate how changes in the variability of income from each source are likely to affect total income inequality (Kimhi, 2007). Perhaps a more policy-relevant result is the impact on inequality of a uniform change in a particular income source. Shorrocks (1983) has noted that comparing $s^{k}$, the contribution of income source $k$ to inequality, and $\mu^{k} / \mu$, the income share of source $k$, is useful for knowing whether the $k^{\text {th }}$ income source is equalizing or disequalizing. Lerman and Yitzhaki (1985) have shown that the relative change in the Gini inequality index following a uniform percentage change in $\mathbf{y}^{k}$ is $\left(s^{k}-\mu^{k} / \mu\right) \mathrm{G}(\mathbf{y})$. Kimhi (2007) has shown that a similar result can be obtained for other inequality measures, including the squared coefficient of variation, using simulations.

\section{Inequality Impacts of Domestic and International Remittances}

The data used in this research is obtained from the 1992 Family Expenditure Survey in the Dominican Republic. The survey included about 1,200 households. Besides detailed income and expenditure data, it included demographic and socio-economic data such as age, education, and labor supply of all household members, detailed information on agricultural activities, and indices of living conditions. The first column in table 1 shows the distribution of per-capita income across income sources. Labor income comprises the lion's share of per-capita income, with capital income (pensions, insurance and interest) in second place. Domestic remittances account for only one percent of per-capita income, while international remittances account for six percent. 
Table 1. Inequality Decomposition by Income Source

\begin{tabular}{|c|c|c|c|c|c|}
\hline & \multicolumn{3}{|c|}{ Inequality contributions } & \multicolumn{2}{|c|}{ Marginal effects } \\
\hline & $\begin{array}{c}\text { per-capita } \\
\text { income }\end{array}$ & Gini* & $\begin{array}{c}\text { Squared } \\
\mathrm{CV}^{*}\end{array}$ & Gini* & $\begin{array}{c}\text { Squared } \\
\mathrm{CV}^{*}\end{array}$ \\
\hline Inequality index & & 0.5149 & 2.4219 & & \\
\hline \multicolumn{6}{|l|}{ Inequality contributions } \\
\hline Wage labor income & $32 \%$ & $\begin{array}{l}0.2460 \\
(8.35)\end{array}$ & $\begin{array}{l}0.1704 \\
(2.94)\end{array}$ & $\begin{array}{c}-0.0445 \% \\
(-3.12)\end{array}$ & $\begin{array}{c}-0.2545 \% \\
(-1.96)\end{array}$ \\
\hline Self-employment income & $30 \%$ & $\begin{array}{l}0.3628 \\
(9.23)\end{array}$ & $\begin{array}{l}0.3642 \\
(3.27)\end{array}$ & $\begin{array}{c}0.0680 \% \\
(3.68)\end{array}$ & $\begin{array}{l}0.1200 \% \\
(0.67)\end{array}$ \\
\hline Agricultural income & $7 \%$ & $\begin{array}{l}0.0522 \\
(3.60)\end{array}$ & $\begin{array}{l}0.0308 \\
(1.77)\end{array}$ & $\begin{array}{c}-0.0113 \% \\
(-1.62)\end{array}$ & $\begin{array}{c}-0.0684 \% \\
(-2.07)\end{array}$ \\
\hline Family business income & $7 \%$ & $\begin{array}{l}0.1302 \\
(3.29)\end{array}$ & $\begin{array}{l}0.3013 \\
(2.00)\end{array}$ & $\begin{array}{l}.0443 \% \\
(2.37)\end{array}$ & $\begin{array}{l}0.4744 \% \\
(1.39)\end{array}$ \\
\hline $\begin{array}{l}\text { Pensions, insurance and } \\
\text { interest income }\end{array}$ & $4 \%$ & $\begin{array}{l}0.0678 \\
(4.34)\end{array}$ & $\begin{array}{l}0.0514 \\
(2.44)\end{array}$ & $\begin{array}{l}.0201 \% \\
(2.77)\end{array}$ & $\begin{array}{l}0.0028 \% \\
(0.11)\end{array}$ \\
\hline Domestic remittances & $1 \%$ & $\begin{array}{l}-0.0029 \\
(-2.49)\end{array}$ & $\begin{array}{l}-0.0015 \\
(-2.77)\end{array}$ & $\begin{array}{c}-0.0155 \% \\
(-7.80)\end{array}$ & $\begin{array}{c}-0.0280 \% \\
(-4.70)\end{array}$ \\
\hline International remittances & $6 \%$ & $\begin{array}{l}0.0563 \\
(5.35)\end{array}$ & $\begin{array}{l}0.0232 \\
(2.43)\end{array}$ & $\begin{array}{c}-0.0017 \% \\
(-0.37)\end{array}$ & $\begin{array}{c}-0.0714 \% \\
(-2.81)\end{array}$ \\
\hline Total & $100 \%$ & 1.00 & 1.00 & & \\
\hline
\end{tabular}

* bootstrapped t-statistics in parentheses.

The second and third columns in table 1 show the inequality decomposition results, and the last two columns show the marginal effects. The decomposition results show that the relative contributions of the income sources roughly correspond to their income shares. The two decomposition rules mostly agree on these relative contributions, with the exception of family business income, which accounts for $13 \%$ of inequality under the Gini decomposition rule and $30 \%$ under the squared $\mathrm{CV}$ rule. The contribution of domestic remittances to inequality is negative. This implies that an increase in the variance of domestic remittances is expected to reduce income inequality. Given that domestic remittances are much more important for poor households (World Bank, 2000), this result is expected. The contribution of international remittances, on the other hand, is positive.

The marginal effects show the percentage impact on inequality of a uniform one-percent increase in each income source. Here we find differences in statistical significance across the two decomposition rules. The income sources that have positive marginal effects on inequality are self-employment, family business, and pensions, insurance and interest income. However, these marginal effects are statistically significant only under the Gini decomposition rule. The 
negative marginal effects of wage labor and agricultural income are statistically significant under both decomposition rules, and the same is true for domestic remittances. International remittances also have a negative marginal effect, but this effect is statistically significant only under the square $\mathrm{CV}$ decomposition rule. Moreover, the marginal effect of domestic remittances is nine times larger than the marginal effect of international remittances (in absolute value) under the Gini decomposition rule, but it is $60 \%$ smaller under the squared $\mathrm{CV}$ decomposition rule.

The results are therefore quite vague with respect to the relative contributions to inequality of domestic and international remittances. However, it is pretty clear that uniform increases in remittances are likely to reduce income inequality. In fact, when the analysis was repeated with total remittances rather than differentiating between domestic and international remittances, the marginal effect of remittances on inequality was significantly negative under both decomposition rules. Combining the decomposition results and the marginal effects, we can say that an increase in domestic remittances is likely to reduce inequality unless the increase is concentrated among households with the lowest levels of domestic remittances (which are likely to be richer overall). An increase in international remittances, on the other hand, is likely to reduce inequality only if it is concentrated among households with the lowest levels of international remittances (which are likely to be poor). The impact of changes in domestic and international migration on income inequality in the Dominican Republic should be evaluated differentially according to these results.

\section{Differentiating by Population Sub-Groups}

To delve deeper into the issue of differential effects of domestic and international remittances, we recall that the relative importance of domestic and international remittances is not homogeneous across population sub-groups. In particular, domestic remittances are more important as a source of income for poor households, while international remittances are more important for richer households (World Bank, 2000). Poverty and inequality are also not homogeneous across population sub-groups. In particular, they have a strong geographic dimension (World Bank, 2006). Table 2 shows the relative importance of income sources to household income of different population sub-groups. Comparing urban and rural households, we find that relatively more rural households enjoy domestic remittances, while many more urban households enjoy international remittances. This is explained by the inability of poor rural households to afford sending a migrant out of the country, and by the fact that many urban households are already residing not far from a well-developed labor market, hence domestic migration is not relevant for them. This last argument is supported by the fact that among urban households, fewer households enjoy domestic remittances in the Santo Domingo area (the major urban center in the country) than elsewhere. We also find that among rural households, households with land (which are supposedly more affluent) are more likely to enjoy domestic remittances than landless households, and the fraction of their international remittances out of total income is twice as high as the same fraction for landless households. 
Table 2. The Distribution of Income Sources by Population Sub-Groups

\begin{tabular}{|c|c|c|c|c|c|c|}
\hline & \multicolumn{3}{|c|}{ urban } & \multicolumn{3}{|c|}{ rural } \\
\hline & \multicolumn{3}{|c|}{ Santo } & \multirow[b]{3}{*}{ total } & \multirow[b]{3}{*}{ landed } & \multirow[b]{3}{*}{ landless } \\
\hline & & Domingo & & & & \\
\hline & total & area & other & & & \\
\hline Percentage of households & 53 & 25 & 28 & 47 & 23 & 24 \\
\hline \multicolumn{7}{|c|}{ Percentage of households with income from: } \\
\hline Wage labor & 67 & 73 & 60 & 56 & 51 & 61 \\
\hline Self-employment & 51 & 57 & 48 & 38 & 29 & 45 \\
\hline Agriculture & 12 & 2 & 25 & 55 & 91 & 24 \\
\hline Family business & 13 & 13 & 14 & 20 & 20 & 20 \\
\hline Pensions, insurance and interest & 39 & 43 & 34 & 22 & 16 & 27 \\
\hline Domestic remittances & 17 & 11 & 26 & 26 & 29 & 22 \\
\hline International remittances & 39 & 40 & 36 & 21 & 21 & 21 \\
\hline \multicolumn{7}{|c|}{ Percentage of household income from: } \\
\hline Wage labor & 40 & 39 & 41 & 30 & 21 & 39 \\
\hline Self-employment & 37 & 38 & 37 & 27 & 17 & 37 \\
\hline Agriculture & 2 & 1 & 1 & 23 & 44 & 2 \\
\hline Family business & 8 & 10 & 9 & 9 & 7 & 12 \\
\hline Pensions, insurance and interest & 5 & 5 & 6 & 2 & 1 & 2 \\
\hline Domestic remittances & 1 & 0 & 1 & 2 & 2 & 2 \\
\hline International remittances & 7 & 6 & 6 & 6 & 8 & 4 \\
\hline Total & 100 & 100 & 100 & 100 & 100 & 100 \\
\hline
\end{tabular}

\begin{tabular}{lcccccc} 
& \multicolumn{2}{c}{ Gender* } & \multicolumn{2}{c}{ Age* } & \multicolumn{2}{c}{ Schooling* } \\
\hline & Male & Female & Up to 50 & 51 plus & Up to 8 & 9 plus \\
\hline Percentage of households & 78 & 22 & 61 & 39 & 78 & 22 \\
Percentage of households with income & from: & & & & & \\
Wage labor & 64 & 55 & 67 & 55 & 59 & 73 \\
Self-employment & 47 & 40 & 49 & 39 & 43 & 53 \\
Agriculture & 36 & 15 & 28 & 37 & 36 & 14 \\
Family business & 17 & 14 & 17 & 15 & 17 & 14 \\
Pensions, insurance and interest & 31 & 32 & 28 & 36 & 27 & 46 \\
Domestic remittances & 18 & 33 & 14 & 31 & 25 & 8 \\
International remittances & 25 & 48 & 28 & 34 & 29 & 37 \\
Percentage of household income from & & & & & & \\
Wage labor & 36 & 44 & 32 & 32 & 29 & 37 \\
Self-employment & 36 & 23 & 32 & 25 & 25 & 36 \\
Agriculture & 9 & 2 & 6 & 8 & 10 & 1 \\
Family business & 9 & 6 & 10 & 3 & 7 & 7 \\
Pensions, insurance and interest & 4 & 5 & 2 & 6 & 3 & 5 \\
Domestic remittances & 1 & 4 & 1 & 2 & 2 & 0 \\
International remittances & 5 & 16 & 5 & 7 & 6 & 4 \\
Total & 100 & 100 & 100 & 100 & 100 & 100 \\
\hline
\end{tabular}

* Gender, age and schooling relate to the head of household. 
Another population sub-group that seems to be unique with respect to the composition of income is female-headed households. These households are much more likely to obtain domestic and international remittances, and the fraction of remittances in total household income is also much higher. It could be that the mere fact that many of these households are headed by a female is a result of the migration of the male spouse either domestically or internationally. Differentiating by households according to the age of the head of household, we find that older households are more likely to obtain remittances, and the difference is particularly notable with respect to domestic remittances. Similar differences are observed with respect to the share of remittances out of total household income. Finally, differentiating by households according to the schooling of the head of household, we find that more educated households are less likely to obtain domestic remittances and more likely to obtain international remittances. Despite that, the share of international remittances out of total household income is lower in more educated households.

It would thus be interesting to look at the differential marginal effects of income from domestic and international remittances on inequality for each population sub-group. Table 3 shows simulated marginal effects of uniform increases in remittances broken down by those same population sub-groups that were presented in table 2. Comparing rural and urban households, we observe that using the Gini inequality index, the negative marginal effect of domestic remittances is much larger for rural than for urban households. However, the marginal effect on the squared $\mathrm{CV}$ inequality index is split almost evenly between these sub-groups. On the other hand, the marginal effect of international remittances is much larger (in absolute value) among urban households, using the squared CV inequality index. The marginal effects under the Gini index are not statistically significant. This is consistent with our earlier result that domestic remittances are more important for rural households, while international remittances are more important for urban households.

The marginal effects of remittances among rural households are further broken down to households with land and landless households. It is easy to see that the negative marginal effects of both domestic and international remittances are larger in absolute value among landless households, for both inequality measures. The marginal effects of remittances among urban households are further broken down to households in the Santo Domingo area and in other areas. We find that marginal effects of remittances in the Santo Domingo area are weaker than in other urban areas, and the marginal effect of international remittances on the Gini inequality index even becomes positive for these households.

Looking at female-headed and male-headed households, we find that the negative marginal effects of remittances on inequality are stronger for female-headed households. Although the differences in table 3 do not seem to be impressive, note that female-headed households are less than a quarter of all households (table 2), and hence their relative marginal effects are indeed stronger. Differentiating by the age of head of household, we find that the negative marginal effect of domestic remittances is stronger for older households, while the marginal effects of international remittances do not seem to vary by the age of head of household. Differentiating by the schooling of head of household, we find that the marginal effects of domestic remittances are consistently and significantly negative only for lower-educated 
households. This difference is also observed with respect to international remittances, but in this case, it is not very consistent across the two inequality measures.

Table 3. Breaking Down the Marginal Effects of Remittances on Inequality*

\begin{tabular}{|c|c|c|c|c|}
\hline & \multicolumn{2}{|c|}{ Domestic remittances } & \multicolumn{2}{|c|}{ International remittances } \\
\hline & Gini & Squared CV & Gini & Squared CV \\
\hline \multirow{2}{*}{ Total marginal effect } & $-0.0155 \%$ & $-0.0280 \%$ & $-0.0017 \%$ & $-0.0714 \%$ \\
\hline & $(-7.80)$ & $(-4.70)$ & $(-0.37)$ & $(-2.81)$ \\
\hline \multirow{2}{*}{ Rural } & $-0.0099 \%$ & $-0.0146 \%$ & $-0.0020 \%$ & $-0.0197 \%$ \\
\hline & $(-6.83)$ & $(-4.53)$ & $(-0.75)$ & $(-2.82)$ \\
\hline \multirow{2}{*}{ With land } & $-0.0039 \%$ & $-0.0053 \%$ & $0.0004 \%$ & $-0.0076 \%$ \\
\hline & $(-4.57)$ & $(-4.06)$ & $(0.16)$ & $(-1.75)$ \\
\hline \multirow{2}{*}{ Landless } & $-0.0060 \%$ & $-0.0094 \%$ & $-0.0024 \%$ & $-0.0121 \%$ \\
\hline & $(-2.49)$ & $(-3.77)$ & $(-2.44)$ & $(-3.11)$ \\
\hline \multirow{2}{*}{ Urban } & $-0.0057 \%$ & $-0.0126 \%$ & $0.0009 \%$ & $-0.0450 \%$ \\
\hline & $(-4.79)$ & $(-3.65)$ & $(0.21)$ & $(-1.99)$ \\
\hline \multirow{2}{*}{ Santo Domingo area } & $-0.0015 \%$ & $-0.0034 \%$ & $0.0062 \%$ & $-0.0165 \%$ \\
\hline & $(-2.07)$ & $(-2.13)$ & $(1.66)$ & $(-1.01)$ \\
\hline \multirow{2}{*}{ Other areas } & $-0.0043 \%$ & $-0.0092 \%$ & $-0.0053 \%$ & $-0.0286 \%$ \\
\hline & $(-4.48)$ & $(-3.60)$ & $(-3.55)$ & $(-3.62)$ \\
\hline \multirow{2}{*}{ Female-headed } & $-0.0082 \%$ & $-0.0152 \%$ & $-0.0024 \%$ & $-0.0357 \%$ \\
\hline & $(-5.05)$ & $(-3.84)$ & $(-0.68)$ & $(-2.37)$ \\
\hline \multirow{2}{*}{ Male-headed } & $-0.0075 \%$ & $-0.0121 \%$ & $0.0014 \%$ & $-0.0291 \%$ \\
\hline & $(-6.25)$ & $(-4.31)$ & $(0.38)$ & $(-1.93)$ \\
\hline \multirow{2}{*}{ Age up to 50} & $-0.0050 \%$ & $-0.0079 \%$ & $0.0008 \%$ & $-0.00315 \%$ \\
\hline & $(-4.36)$ & $(-3.44)$ & $(0.22)$ & $(-1.86)$ \\
\hline \multirow{2}{*}{ Age 51 and up } & $-0.0101 \%$ & $-0.0184 \%$ & $-0.0002 \%$ & $-0.0332 \%$ \\
\hline & $(-6.95)$ & $(-3.82)$ & $(-0.05)$ & $(-2.17)$ \\
\hline \multirow{2}{*}{ Schooling up to 8 years } & $-0.0151 \%$ & $-0.0252 \%$ & $-0.0039 \%$ & $-0.0543 \%$ \\
\hline & $(-8.02)$ & $(-4.14)$ & $(-0.88)$ & $(-2.58)$ \\
\hline \multirow{2}{*}{ Schooling 9 years and up } & $-0.0000 \%$ & $-0.0011 \%$ & $0.0044 \%$ & $-0.0104 \%$ \\
\hline & $(-0.22)$ & $(-1.82)$ & $(1.68)$ & $(-0.91)$ \\
\hline
\end{tabular}

* Bootstrapped t-statistics in parentheses. Age and schooling are of the head of household.

The results of this simulation exercise imply that while the equalizing nature of uniform increases in remittances is valid for almost all population sub-groups, it is stronger for population sub-groups that are comprised of relatively low-income households, such as rural landless households, urban households outside of the Santo-Domingo area, female-headed households, and the less educated. This implies that understanding the determinants of both 
rural-to-urban and international migration of low-income households is critical to the design of inequality-reducing policy measures. For example, education is known to be an important determinant of migration (Adams, 2003), although its effect varies considerably across countries (Acosta et al., 2008). If education stimulates migration, as seems to be the case for the Dominican Republic, then enhancing education among poorer households could have an equalizing effect on income through its effect on remittances. In the next section, we attempt to identify the determinants of remittances and their inequality implications.

\section{The Determinants of Remittances and Their Inequality Implications}

Table 4. Tobit Results

\begin{tabular}{|c|c|c|c|}
\hline \multirow[b]{2}{*}{ Explanatory variable } & \multirow[b]{2}{*}{ Sample mean } & \multicolumn{2}{|c|}{$\ln ($ remittances per capita) } \\
\hline & & Domestic & International \\
\hline \multirow[t]{2}{*}{ Intercept } & 1.00 & -6.81 & -6.98 \\
\hline & & $(-4.75)^{* *}$ & $(-5.28)^{* *}$ \\
\hline \multirow[t]{2}{*}{ Female-headed household } & 0.22 & 4.07 & 4.29 \\
\hline & & $(5.00)^{* *}$ & $(6.06)^{* *}$ \\
\hline \multirow[t]{2}{*}{ Age above 50} & 0.39 & 3.66 & 1.62 \\
\hline & & $(4.95)^{* *}$ & $(2.50)^{*}$ \\
\hline \multirow[t]{2}{*}{ Schooling 1 to 8 years } & 0.59 & -0.42 & 2.19 \\
\hline & & $(-0.49)$ & $(2.53)^{* *}$ \\
\hline \multirow[t]{2}{*}{ Schooling above 8 years } & 0.22 & -3.65 & 3.30 \\
\hline & & $(-2.87)^{* *}$ & $(3.11)^{* *}$ \\
\hline \multirow[t]{2}{*}{ Family size } & 5.15 & -0.14 & 0.04 \\
\hline & & $(-0.99)$ & $(0.28)$ \\
\hline \multirow[t]{2}{*}{ Household with land } & 0.31 & 1.54 & 1.54 \\
\hline & & $(1.48)$ & $(1.53)$ \\
\hline \multirow[t]{2}{*}{$\ln$ (landholdings per capita) } & 0.51 & -0.28 & 0.01 \\
\hline & & $(-0.72)$ & $(0.02)$ \\
\hline \multirow[t]{2}{*}{ Rural } & 0.47 & 0.62 & -3.16 \\
\hline & & $(0.80)$ & $(-4.41)^{* *}$ \\
\hline \multirow[t]{2}{*}{ Santo Domingo area } & 0.30 & -3.11 & 0.83 \\
\hline & & $(-3.37)^{* *}$ & $(1.11)$ \\
\hline \multirow[t]{2}{*}{ Santiago area } & 0.09 & -1.30 & 3.26 \\
\hline & & $(-1.01)$ & $(3.09)^{* *}$ \\
\hline Sigma & & 8.03 & 7.89 \\
\hline Pseudo $\mathrm{R}^{2}$ & & 0.0515 & 0.0333 \\
\hline Likelihood ratio & & $126.83 * *$ & $105.56^{* *}$ \\
\hline Number of observations & & 1089 & 1089 \\
\hline$\%$ censored & & $79 \%$ & $69 \%$ \\
\hline
\end{tabular}

$*$ significant at $5 \% ; * *$ significant at $1 \%$. 
A regression analysis is used to identify and quantify the effects of the determinants of remittances. Per-capita domestic and international remittances are analyzed separately, and a Tobit model is used since both types of remittances are censored from below at zero. The results are in table 4. The models were estimated with and without a log-transformation of the dependent variables. The results were not too different, therefore only the log-transformation results are presented. The results show that both domestic and international remittances are higher in female-headed households and in households in which the head of household is older. Schooling, on the other hand, affects domestic remittances negatively and international remittances positively. This implies selectivity on schooling in the migration decision, with the less educated migrating internally and the more educated migrating internationally. This conclusion, of course, depends on the presumption that schooling of the household head is a good proxy for the schooling of migrant household members. Family size and landholdings do not have statistically significant effects on per-capita remittances. The geographic differences in migration patterns are also visible here, with domestic remittances lower in the Santo Domingo area, and international remittances lower in rural areas and higher in the Santiago area (the secondary urban center in the Dominican Republic).

The estimated regression coefficients can now be used in order to further decompose the part of income inequality that operates through remittances. Morduch and Sicular (2002) and Fields (2003) suggested a regression-based inequality decomposition by income determinants. In particular, total household income is specified as a linear regression:

(4) $\mathbf{y}=\mathbf{X} \boldsymbol{\beta}+\boldsymbol{\varepsilon}$,

where $\mathbf{X}$ is a matrix of explanatory variables, $\boldsymbol{\beta}$ is a vector of coefficients, and $\boldsymbol{\varepsilon}$ is a vector of residuals. Given a vector of consistently estimated coefficients $\mathbf{b}$, income can be expressed as a sum of predicted income and a prediction error according to:

(5) $\mathbf{y}=\mathbf{X b}+\mathbf{e}$

Substituting (5) into (1) and dividing through by $I(\mathbf{y})$, the share of inequality attributed to explanatory variable $m$ is obtained as:

(6) $s^{m}=b_{m} \Sigma_{i} a_{i}(\mathbf{y}) x_{i}^{m} / I(\mathbf{y})$.

Arayama et al. (2009) develop this decomposition method further in order to differentiate between contributions of explanatory variables through different income sources. In particular, they specify the $k^{\text {th }}$ source-specific income-generating function as:

(7) $\mathbf{y}_{k}=\mathbf{X} \boldsymbol{\beta}_{k}+\boldsymbol{\varepsilon} k$,

where $\boldsymbol{\beta}_{k}$ could include zero elements corresponding to explanatory variables that do not affect the $k^{\prime}$ th source of income. Since $\mathbf{y}=\Sigma_{k} \mathbf{y}_{k}=\mathbf{X} \Sigma_{k} \boldsymbol{\beta}_{k}+\Sigma_{k} \boldsymbol{\varepsilon}_{k}$, using consistent estimates $\mathbf{b}_{k}$ of $\boldsymbol{\beta}_{k}$ and substituting into (1), the share of inequality attributed to explanatory variable $m$ in overall 
inequality becomes:

(6)' $s^{m}=\left(\sum_{k} b_{k m}\right) \sum_{i} a_{i}(\mathbf{y}) x_{i}^{m} / I(\mathbf{y})$.

This can be broken down to source-specific contributions of each explanatory variable to overall inequality, denoted $s^{m k}$, which is implicitly defined by:

(8) $s^{m}=\Sigma_{k}\left[b_{k m} \Sigma_{i} a_{i}(\mathbf{y}) x_{i}^{m} / I(\mathbf{y})\right]=\Sigma_{k} s^{m k}$.

The tobit coefficients in table 4 are used for $\mathbf{b}_{k}$ in (8). The results are in table 5. Recall that the contributions of domestic and international remittances to total income inequality were negative and positive, respectively (table 1). Table 5 shows that these contributions are mostly driven by the distributions of schooling and geographical location. The distribution of family size, on the other hand, contributes positively to inequality through both domestic and international remittances, while the distribution of landholdings (in particular, households with and without land) contributes negatively to inequality through both domestic and international remittances.

Another way to look at the impact of explanatory variables on inequality is through marginal effects. We use simulations to compute marginal effects in the following way. First, we make a change in an explanatory variable. Then, we use the regression coefficients in order to predict the resulting change in income from remittances. Finally, we compute the level of inequality of total income after incorporating this change. The changes in the explanatory variables used in this case are the following. Family size is increased by one person for the whole sample, landholdings per capita are increased by $1 \%$, and each of the categorical variables is changed to 1 for the whole sample. Note that the results are not comparable to those reported in table 3 . There, remittance income was increased by $1 \%$ for all rural households (for example), while here, remittance income of urban households is changed as if they were rural. Also, in the case of the categorical variables, the simulation obviously reduces the variance of the variable to zero, and hence the results are not independent of the inequality contributions reported in table 5. However, note that the variance can be reduced to zero by either changing the categorical variable to one or to zero, and the marginal effects are going to be of opposite signs in those two cases. 


\section{Ml Macrothink}

Table 5. Source-Specific Contributions to Total Income Inequality of Determinants of Remittances*

\begin{tabular}{lcccc}
\hline & \multicolumn{2}{c}{ Domestic remittances } & \multicolumn{2}{c}{ International remittances } \\
\hline Explanatory variable & Gini & $\mathrm{CV}^{2}$ & Gini & $\mathrm{CV}^{2}$ \\
\hline Intercept & 0.00000 & 0.00000 & 0.00000 & 0.00000 \\
Female-headed household & $(0.13)$ & $(0.06)$ & $(0.13)$ & $(0.10)$ \\
& -0.00098 & -0.00082 & -0.00316 & -0.00272 \\
Age above 50 & $(-0.96)$ & $(-1.66)$ & $(-0.95)$ & $(-1.62)$ \\
& -0.00087 & -0.00027 & -0.00099 & -0.00030 \\
Schooling 1 to 8 years & $(-0.94)$ & $(-0.54)$ & $(-0.66)$ & $(-0.34)$ \\
& 0.00014 & 0.00013 & -0.00524 & -0.00495 \\
Schooling above 8 years & $(1.97)$ & $(2.30)$ & $(-2.11)$ & $(-2.55)$ \\
& -0.00753 & -0.00373 & 0.02665 & 0.01357 \\
Family size & $(-8.23)$ & $(-3.37)$ & $(9.55)$ & $(3.75)$ \\
& 0.00361 & 0.00120 & 0.00771 & 0.00260 \\
Household with land & $(8.68)$ & $(4.64)$ & $(8.64)$ & $(4.86)$ \\
& -0.00095 & -0.00027 & -0.01249 & -0.00360 \\
ln(landholdings per capita) & $(-5.92)$ & $(-2.60)$ & $(-5.37)$ & $(-2.72)$ \\
& 0.00011 & 0.00002 & 0.00069 & 0.00010 \\
Rural & $(1.25)$ & $(0.32)$ & $(1.07)$ & $(0.29)$ \\
Santo Domingo area & -0.00140 & -0.00052 & 0.02738 & 0.01033 \\
Santiago area & $(-9.53)$ & $(-4.62)$ & $(9.57)$ & $(4.83)$ \\
Residual & -0.00717 & -0.00341 & 0.01262 & 0.00609 \\
Total (from table 1) & $(-8.29)$ & $(-4.38)$ & $(8.72)$ & $(4.64)$ \\
& -0.00035 & 0.00001 & 0.00235 & 0.00010 \\
& $(-1.77)$ & $(0.15)$ & $(1.63)$ & $(0.17)$ \\
& 0.01214 & 0.00633 & 0.11160 & 0.00418 \\
& $(6.40)$ & $(3.87)$ & $(15.8)$ & $(0.76)$ \\
& -0.00298 & -0.00140 & 0.05630 & 0.02323 \\
& $(-2.44)$ & $(-2.27)$ & $(5.35)$ & $(2.43)$ \\
\hline
\end{tabular}

* Bootstrapped t-statistics in parentheses.

The results are in table 6. Marginal effects of female-headed households, age above 50, and land ownership are negative for both domestic and international remittances. On the other hand, marginal effects of family size and landholdings are positive for both domestic and international remittances. The marginal effect of higher education is positive in the case of domestic remittances and negative in the case of international remittances, and the same is true for the marginal effects of the urban centers (Santo Domingo and Santiago). The marginal effect of rural households is negative in the case of domestic remittances and positive in the case of international remittances. 
Table 6. Marginal Effects of Determinants of Remittances on Total Income Inequality*

\begin{tabular}{lrrrr}
\hline & \multicolumn{2}{c}{ Domestic remittances } & \multicolumn{2}{c}{ International remittances } \\
\cline { 2 - 5 } Explanatory variable & \multicolumn{1}{c}{ Gini } & \multicolumn{1}{c}{$\mathrm{CV}^{2}$} & \multicolumn{1}{c}{ Gini } & \multicolumn{1}{c}{$\mathrm{CV}^{2}$} \\
\hline Female-headed household & $-5.072 \%$ & $-9.917 \%$ & $-14.922 \%$ & $-28.889 \%$ \\
Age above 50 & $-3.251 \%$ & $-6.513 \%$ & $-4.859 \%$ & $-9.790 \%$ \\
Schooling 1 to 8 years & $-0.323 \%$ & $-1.453 \%$ & $-2.963 \%$ & $-4.177 \%$ \\
Schooling above 8 years & $5.027 \%$ & $9.216 \%$ & $-7.709 \%$ & $-13.135 \%$ \\
Family size & $0.407 \%$ & $0.802 \%$ & $0.869 \%$ & $1.712 \%$ \\
Household with land & $-0.596 \%$ & $-1.303 \%$ & $-6.823 \%$ & $-14.998 \%$ \\
ln(landholdings per capita) & $0.002 \%$ & $0.005 \%$ & $0.016 \%$ & $0.031 \%$ \\
Rural & $-0.274 \%$ & $-0.717 \%$ & $6.700 \%$ & $16.121 \%$ \\
Santo Domingo area & $3.973 \%$ & $6.990 \%$ & $-5.359 \%$ & $-9.043 \%$ \\
Santiago area & $1.305 \%$ & $1.659 \%$ & $-11.097 \%$ & $-19.513 \%$ \\
\hline
\end{tabular}

* All marginal effects are highly significant; t-values were suppressed.

These results have a number of policy implications. Increasing the variance of schooling (by increasing schooling of households who are already more educated than the average) is expected to decrease domestic remittances and increase international remittances, probably through substitution of international migration for domestic migration. This is expected to increase income of these households, but since the impacts of schooling through domestic and international remittances are opposite in signs, the overall impact on income inequality is ambiguous. It depends on the initial position of these households within the income distribution. Similarly, migration of entire households from remote rural areas to central urban areas is expected to reduce domestic remittances and increase international remittances for these households, and the resulting effect on income inequality is ambiguous. A family planning policy that reduces fertility and therefore household size especially among the larger households is expected to reduce household size inequality, and according to table 5 this would reduce inequality through its impact on remittances. This policy would also reduce average household size and this would also reduce inequality through its effect on remittances (table 6). Hence, the impact of this policy on inequality (through remittances) is unambiguously negative. Finally, consider a land reform that allocates farmland to some landless households. This increases the variance of landlessness to the extent that less than half of the household's own land, and hence reduces inequality according to table 5 . This policy also reduces inequality according to table 6 because it increases the fraction of households with land. The bottom line seems to be unambiguous, but note that this policy would also change the distribution of landholdings per capita, and this could change the picture.

\section{Summary and Conclusions}

This paper used inequality decomposition techniques to analyze the differential roles of domestic and international remittances in determining household income inequality in the 
Dominican Republic. Decomposing total income inequality by income sources reveals that the variability of international remittances contributes positively to inequality, while the contribution of the variability of domestic remittances is negative. This is consistent with the findings of Taylor et al. (2008) for Mexico and those of Olowa and Shittu (2012) for Nigeria. However, the marginal effect on inequality of a uniform increase in remittances is negative for both domestic and international remittances. Combining the results of the decomposition and the marginal effects, one can conclude that domestic remittances are more likely to be equalizing than international remittances. Breaking down the marginal effects by population sub-groups, we found that the negative marginal effect on inequality of domestic remittances is more prominent among rural households, and in particular among landless rural households, while the negative marginal effect on inequality of international remittances is more prominent among urban households, and in particular outside of the Santo Domingo area. Stronger marginal effects of remittances were also found among female-headed households, the elderly and the less educated. The conclusion is that the impact of remittances on inequality is far from being uniform across the population.

Analyzing the determinants of remittances, we found that both domestic and international remittances are higher among female-headed households and the elderly. Education seems to be associated with lower domestic remittances and higher international remittances, probably reflecting the role of education in promoting international versus domestic migration. Geographic differences in the levels of remittances are also observed. Breaking down the contributions of remittances to inequality into shares attributed to these inequality determinants, we found that an increase in schooling increases inequality through domestic remittances and decreases inequality through international remittances, while a reduction in household size is likely to reduce inequality through both domestic and international remittances. These results could be useful for policy evaluations.

The analysis of this paper highlights the importance of the distinction between domestic and international remittances as drivers of inequality in the case of the Dominican Republic. It also emphasized the importance of identifying and quantifying the determinants of remittances and their subsequent impact on inequality. Still, the analysis is partial in the sense that it does not explicitly model the incidence of remittances. Recall that a Tobit model was used to estimate the determinants of remittances, but the coefficients were used in the decomposition procedure as if remittances are not censored. A more complete analysis should evaluate the marginal effects of determinants of remittances on the incidence if remittances as well as their level. In addition, the analysis focused on remittances and somewhat neglected the changes in other income sources as remittances change. This topic is left for future research.

\section{Acknowledgement}

The research is financed in part by the Center for Agricultural Economic Research. 


\section{References}

Acosta, Pablo, Cesar Calderón, Pablo Fajnzylber \& Humberto Lopez. (2008). What is the Impact of International Remittances on Poverty and Inequality in Latin America? World Development, 36, 89-114. https://doi.org/10.1016/j.worlddev.2007.02.016

Adams Jr., \& Richard H. (2011). Evaluating the economic impact of international remittances on developing countries using household surveys: A literature review. Journal of Development Studies, 47(6), 809-828. https://doi.org/10.1080/00220388.2011.563299

Adams, Jr., \& Richard H. (2003). International Migration, Remittances, and the Brain Drain: A Study of 24 Labor-Exporting Countries. World Bank Policy Research Working Paper No. 3069. https://doi.org/10.1596/1813-9450-3069

Adams, Jr., Richard H., \& John Page (2005). Do International Migration and Remittances Reduce Poverty in Developing Countries? World Development, 33, 1645-1669. https://doi.org/10.1016/j.worlddev.2005.05.004

Arayama, Yuko, Jong Moo Kim \& Ayal Kimhi (2009). Identifying Determinants of Income Inequality in the Presence of Multiple Income Sources: The Case of Korean Farm Households. Discussion Paper No. 06.09, The Center for Agricultural Economic Research, Rehovot, Israel.

Azizi, SeyedSoroosh (forthcoming). The impacts of workers' remittances on poverty and inequality in developing countries. Empirical Economics.

Bang, James T., Aniruddha Mitra \& Phanindra V. Wunnava. (2016). Do remittances improve income inequality? An instrumental variable quantile analysis of the Kenyan case. Economic Modelling, 58, 394-402. https://doi.org/10.1016/j.econmod.2016.04.004

Brown, Richard P. C., \& Eliana Jimenez-Soto. (2015). Migration and remittances. Handbook of the economics of international migration, 1(North-Holland), 1077-1140. https://doi.org/10.1016/B978-0-444-53768-3.00020-5

Carneiro, Francisco Galrao, Cecile Thioro Niang, Gianluca Mele, Christine Lao Pena, Mark Lambrides, Laura Wendell, Juan Carlos Parra Osorio \& Jean-Martin Brault. (2016). Building a better future together: Dominican Republic policy notes. Washington, D.C.: World Bank Group.

Fajnzylber, Pablo \& J. Humberto Lopez (2008). The Development Impact of Remittances in Latin America. In Pablo Fajnzylber and J. Humberto Lopez (Eds.), Remittances and Development: Lessons from Latin America. Washington: The World Bank, 1-19. https://doi.org/10.1596/978-0-8213-6870-1_ch01

Fields, Gary. (2003). Accounting for Income Inequality and Its Change: A New Method, with Application to the Distribution of Earnings in the United States. Research in Labor Economics, 22, 1-38. https://doi.org/10.1016/S0147-9121(03)22001-X

Imai, Katsushi S., Raghav Gaiha, Abdilahi Ali \& Nidhi Kaicker. (2014). Remittances, growth 
and poverty: New evidence from Asian countries. Journal of Policy Modeling, 36(3), 524538. https://doi.org/10.1016/j.jpolmod.2014.01.009

Jimenez-Soto, Eliana V., \& Richard PC Brown (2012). Assessing the poverty impacts of migrants' remittances using propensity score matching: The case of Tonga. Economic Record, 88(282), 425-439. https://doi.org/10.1111/j.1475-4932.2012.00824.x

Kimhi, Ayal. (2007). Regression-Based Inequality Decomposition: A Critical Review and Application to Farm-Household Income Data. Discussion Paper No. 16.07, The Center for Agricultural Economic Research, Rehovot, Israel.

Kóczán, Zsóka, \& Franz Loyola. (2018). How Do Migration and Remittances Affect Inequality? A Case Study of Mexico. IMF Working Paper No. WP/18/136. https://doi.org/10.5089/9781484361634.001

Lerman, Robert I., \& Shlomo Yitzhaki. (1985). Income Inequality Effects by Income Source: A New Approach and Applications to the United States. Review of Economics and Statistics, 67, 151-156. https://doi.org/10.2307/1928447

Möllers, Judith \& Wiebke Meyer. (2014). The effects of migration on poverty and inequality in rural Kosovo. IZA Journal of Labor \& Development, 3(1), 16. https://doi.org/10.1186/2193-9020-3-16

Morduch, Jonathan, \& Terry Sicular. (2002). Rethinking Inequality Decomposition, with Evidence from Rural China. The Economic Journal, 112, 93-106. https://doi.org/10.1111/1468-0297.0j674

Olowa, Olatomide Waheed, \& Adebayo M. Shittu. (2012). Remittances and income inequality in rural Nigeria. Journal of Business Management and Economics, 3(5), 210-221.

Özden, Coglar \& Maurice Schiff. (2006). Overview. In Coglar Özden and Maurice Schiff (Eds.), International Migration, Remittances, and the Brain Drain. New York: Palgrave Macmillan.

Pessar, Patricia R. (1982). The Role of Households in International Migration and the Case of U.S.-Bound Migration from the Dominican Republic. International Migration Review, 16, 342-364. https://doi.org/10.2307/2545102

Pfau, Wade Donald, \& Long Thanh Giang. (2009). Determinants and impacts of international remittances on household welfare in Vietnam. International Social Science Journal, 60, 197-198, 431-443. https://doi.org/10.1111/j.1468-2451.2010.01733.x

Rapoport, Hillel, \& Frederic Docquier (2006). The Economics of Migrants' Remittances. In Serge-Christophe Kolm and Jean Mercier Ythier (Eds.), Handbook on the Economics of Reciprocity, Giving and Altruism, Vol. 2. Amsterdam: Elsevier-North Holland.

Shorrocks, Anthony F. (1982). Inequality Decomposition by Factor Components. Econometric, 50, 193-211. https://doi.org/10.2307/1912537

Shorrocks, Anthony F. (1983). The Impact of Income Components on the Distribution of 
Family Incomes. Quarterly Journal of Economics, 98, 311-326. https://doi.org/10.2307/1885627

Stark, Oded, J. Edward Taylor, \& Shlomo Yitzhaki. (1986). Remittances and Inequality. Economic Journal, 28, 309-22. https://doi.org/10.2307/2232987

Stark, Oded, J. Edward Taylor, \& Shlomo Yitzhaki. (1988). Migration, Remittances and Inequality: A Sensitivity Analysis Using the Extended Gini Index. Journal of Development Economics, 28, 309-22. https://doi.org/10.1016/0304-3878(88)90002-8

Taylor, J. Edward. (1999). The New Economics of Labour Migration and the Role of Remittances in the Migration Process. International Migration, 37, 63-88. https://doi.org/10.1111/1468-2435.00066

Taylor, J. Edward, Jorge Mora, Richard Adams \& Alejandro Lopez-Feldman. (2008). Remittances, Inequality and Poverty: Evidence from Rural Mexico. In Josh DeWind and Jennifer Holdaway (Eds.), Migration and Development Within and Across Borders: Research and Policy Perspectives on Internal and International Migration. New York, NY: The Social Science Research Council, pp. 101-130.

Vacaflores, Diego E. (2018). Are remittances helping lower poverty and inequality levels in Latin America? The Quarterly Review of Economics and Finance, 68, 254-265. https://doi.org/10.1016/j.qref.2017.09.001

World Bank. (2000). Dominican Republic Social and Structural Policy Review. Report No. 20192, Poverty Reduction and Economic Management Unit, Latin America and the Caribbean.

World Bank. (2006). Dominican Republic Poverty Assessment: Achieving More Pro-Poor Growth. Report No. 32422-DO, Caribbean Country Management Unit, Latin America and the Caribbean Region.

\section{Copyright Disclaimer}

Copyright for this article is retained by the author(s), with first publication rights granted to the journal.

This is an open-access article distributed under the terms and conditions of the Creative Commons Attribution license (http://creativecommons.org/licenses/by/3.0/). 